\title{
Optimalisasi Penjualan Produk dan Manajemen Keuangan Melalui Pengelolaan Akuntansi dan Website Penjualan Online Pada Usaha Permen Tradisional "Soba Padu"
}

\author{
Mukhlisulfatih Latief ${ }^{1}$, Moh.Syafri Tuloli ${ }^{2}$, Lanto Miriatin Amali ${ }^{3}$ \\ ${ }^{1}$ Jurusan Teknik Informatika, Fakultas Teknik, Universitas Negeri Gorontalo \\ ${ }^{2}$ Jurusan Teknik Informatika, Fakultas Teknik, Universitas Negeri Gorontalo \\ ${ }^{3}$ Jurusan Manajemen, Fakultas Ekonomi, Universitas Negeri Gorontalo
}

\begin{abstract}
The partner of this Community Partnership Program (PKM) was a "Soba Padu" UKM. The objectives to be achieved in this service activity are (1) providing management / financial management assistance in making simple bookkeeping to partners and (2) providing promotional media and marketing / selling products in the form of a website as well as conducting training on the use of online sales websites to UKM partners "Soba Padu" in Bongomeme Village, Gorontalo District. Specific targets to be achieved are: (1) Availability of online sales website for UKM partners "Soba Padu" (2) There is simple bookkeeping produced by UKM partners "Soba Padu". To achieve these specific goals and targets the method used is through training and mentoring to UKM partners "Soba Padu" with lecture and demonstration techniques and practice. The end results of this Community Service activity are (1) the promotion of products produced by UKM through online sales websites, (2) increased sales of products from UKM "Soba Padu" and (3) creation of regular financial management in accordance with the principles correct financial management.
\end{abstract}

Keywords: Website, Promotion, Selling, Finance

\section{PENDAHULUAN}

Program Kemitraan Masyarakat (PKM) yang telah dilaksanakan bermitra dengan UKM Soba Padu, yang beralamat di Jl. Wa'na Makka No. 17 Bongomeme, Kabupaten Gorontalo, dengan pemilik usaha Ibu Kasmuning Dako.

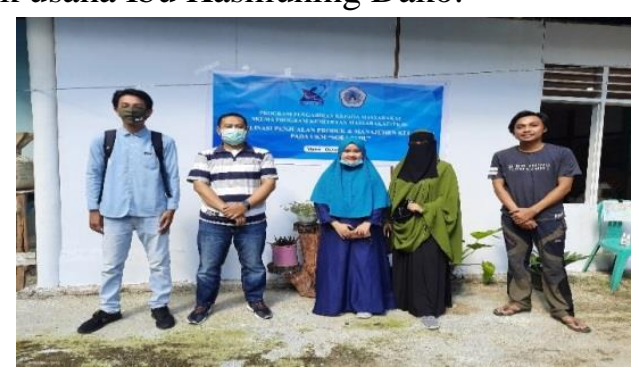

Gambar 1. UKM Mitra PKM

Kondisi UKM mitra sebagai berikut :

Usaha permen tradisional khas Gorontalo "Soba Padu" yang dimiliki oleh ibu Kasmuning Dako sudah berjalan sekitar 5 tahun. Untuk membuat permen soba padu tersebut bahan bakunya adalah gula putih, gula merah dan kacang. Untuk gula putih bahan bakunya di supply dari desa tolangohula yang jaraknya sekitar $70 \mathrm{Km}$ dari rumahnya ibu Kasmuning. Selain itu, untuk mendapatkan gula merah, ibu Kasmuning biasanya membeli dari supermarket. Sedangkan untuk bahan baku kacang diambil dari desa bongomeme yang tidak jauh dari rumah ibu Kasmuning. Untuk pembuatan permen soba ini masih dilakukan peralatan sederhana. Peralatan yang dimiliki ibu Kasmuning untuk membuat permen soba diantaranya adalah alat pemeras kelapa untuk membuat santan dan cukur kelapa. Ditambah lagi dengan dengan peralatan masak seperti kompor gas dan meja etalase seperti pada gambar 2 .

Untuk memasarkan produknya ibu Kasmuning menitipkannya di beberapa supermarket yang ada di Gorontalo seperti Omart, Hipermart, Alfamart dll. Adapun beberapa kota seperti manado, ternate, jayapura, palu, makassar sudah dipasarkan permen ini, tapi masih dalam jumlah yang sedikit. Untuk pemasaran permen Soba ini, ibu Kasmuning hanya menggunakan aplikasi Whatsapp dan Facebook 
untuk menjual produknya. Beberapa kali juga ibu Kasmuning biasa hadir pada event pameran di daerah maupun diluar daerah untuk mempromosikan produknya. Dengan usaha seperti itu, dirasakan oleh ibu Kasmuning belum dapat meningkatkan omzet penjualannya. Untuk memproduksi permen soba ini, ibu Kasmuning mengeluarkan dana sebesar Rp. 500.000 1.000 .000 setiap harinya.

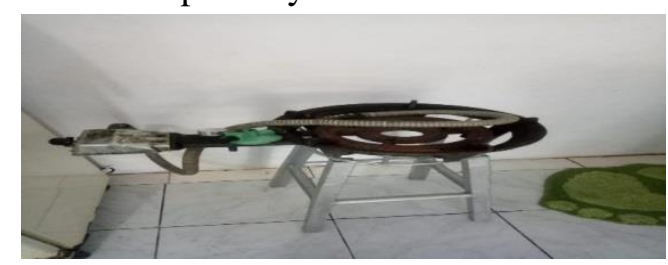

Gambar 2. Peralatan produksi soba padu

Gambar 3 merupakan Kemasan produk dari permen soba padu yang mempunyai 5 jenis variasi. Untuk kemasan plastik mika harganya Rp. 5.000, untuk yang standingpouch 100 gr harganya Rp. 8.500 sedangkan yang standingpouch 200 gr harganya 18.000 serta untuk kemasan dalam bentuk toples harganya Rp. 50.000 per toplesnya. Selain itu, dalam penjualannya permen ini dapat dibeli dengan harga Rp. 1.000 per 6 buah permen dan Rp 100.000 untuk kemasan cendramata atau oleh-oleh ke luar daerah.

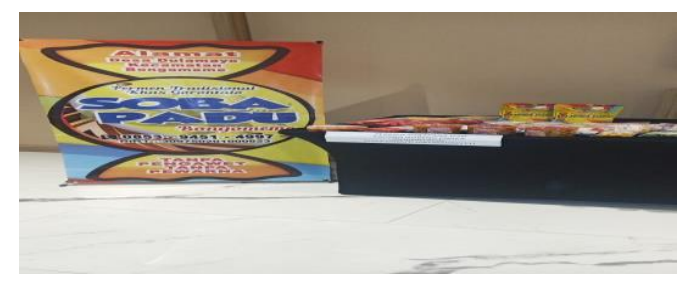

Gambar 3. Berbagai aneka kemasan permen Soba

Dari segi manajemen pengelolaan keuangan, usaha ini masih menggunakan pembukuan yang manual dan sederhana yang dibuat sendiri oleh ibu Kasmuning. Pembukuan tersebut dituliskan pada sebuah buku yang ditulis tangan dan hanya berisi pemasukan dan pengeluaran saja. Hal ini sangat berpengaruh pada evaluasi perkembangan usaha dari segi profit dan pengembalian investasi (bismala, 2016).

Dari perjelasan diatas, dapat disimpulkan bahwa permasalahan mitra adalah sebagai berikut :

1. Bidang Manajemen Keuangan yaitu adanya pembukuan yang masih manual. Dalam sebuah usaha, keterampilan manajemen sangat diperlukan terutaman manajemen keuangan karena berhubungan dengan pengambilan keputusan (muslich, 2003). Dalam penjualan produk permen soba ini, ibu Kasmuning mengalami kesulitan dalam memperhitungkan omset, laba kotor sampai dengan laba bersih karena pembukuan yang masih manual. Pembukuan secara manual ini rawan terjadinya kehilangan, kerusakan dan bahkan kesalahan rekap. Hal ini seringkali membuat usaha tersebut terhambat untuk bisa growth dan scale up bisnisnya. Selain itu ibu kasmuning masih kesulitan untuk memantau arus kas baik arus kas masuk maupun keluar. Kadang-kadang hasil keuntungan produk masih digunakan untuk kepentingan-kepentingan pribadi yang menyebabkan arus kasnya tidak terkontrol. Hal ini membuat pemilik produk sulit untuk menghitung berapa sisa modal yang ada. Hasil penelitian umami (2019) dan supeni dan sari (2011) menunjukkan bahwa pengelolaan manajemen keuangan berpengaruh terhadap usaha mikro kecil dan menengah.

2. Bidang Pemasaran dan Promosi yaitu belum maksimalnya pemasaran secara online. Karena masih menggunakan media sosial seperti Whatsapp dan Facebook, ibu Kasmuning mengalami kesulitan dalam memasarkan produknya. Kesulitan tersebut antara lain adalah sulitnya pelanggan dalam melihat informasi produk-produk yang tersedia di Whasapp dan FB tersebut karena produk yang ditampilkan lewat aplikasi Whatsapp ini sudah tertutup dengan banyaknya komentar yang masuk pada aplikasi tersebut. Disamping itu usaha ini belum memiliki website khususuntuk mempromosikan dan menjual produk permen soba. Hal ini dapat diatasi dengan membuat website pemasaran dan transaksi penjualan seperti dalam penelitian jonathan (2015).

\section{METODE YANG DIGUNAKAN}

\section{Ceramah bervariasi.}

Metode ini dipilih untuk menyampaikan konsep-konsep yang penting untuk dimengerti dan dikuasai oleh peserta pelatihan. Penggunaan 
metode ini dengan pertimbangan bahwa metode ceramah yang dikombinasikan dengan gambargambar, animasi dan display dapat memberikan materi yang relatif banyak secara padat, cepat dan mudah. Materi yang diberikan meliputi: cara mengakses website, membuat, mengelola produk yang akan dijual pada website dan melakukan transaksi penjualan pada website. Selain itu juga disampaikan materi tentang teori akuntansi serta pengelolan keuangan secara sederhana seperti pembuatan jurnal keuangan dll.

Demonstrasi.

Metode ini dipilih untuk menunjukkan suatu proses kerja yaitu tahap-tahap pengelolaan website dan pengelolaan keuangan. Demonstrasi dilakukan oleh instruktur di hadapan peserta yang masingmasing mengoperasikan smartphone sehingga peserta dapat mengamati secara langsung metode dan teknik pengeloaan website dan pengelolaan keuangan.

\section{Latihan.}

Metode ini digunakan untuk memberikan latihan kepada peserta untuk mempraktikkan pengelolaan produk pada website dan pembuatan jurnal keuangan.

\section{PELAKSANAAN DAN HASIL KEGIATAN}

\section{Ceramah tentang pengelolaan website}

Pada tahapan ini, tim pengabdi menunjukkan kepada mitra bagaimana mengelola website terutama cara mengelola data produk, mengelola data pelapak, pembeli,data rekening, data transfer dll. Disamping itu disampaikan pula bagaiman cara mendaftar untuk menjadi pembeli atau penjual.

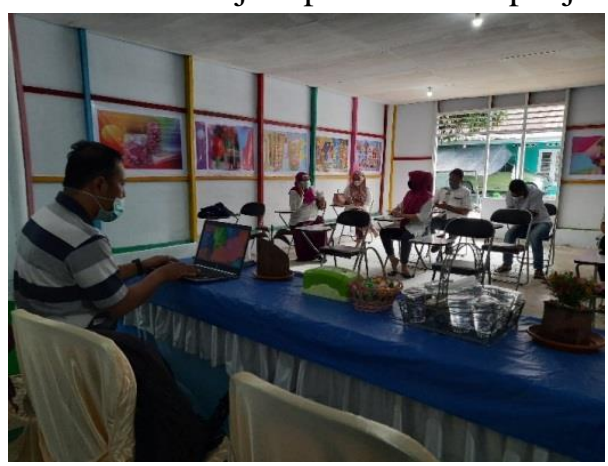

Gambar 4. Ceramah pengelolaan website
2. Ceramah tentang pengertian, tujuan, dan macam-macam laporan keuangan, laporan neraca, laporan arus kas dll

Pada tahapan ini, tim pengabdi menunjukkan kepada mitra bagaimana terori dasar pengelolaan keuangan secara sederhana.

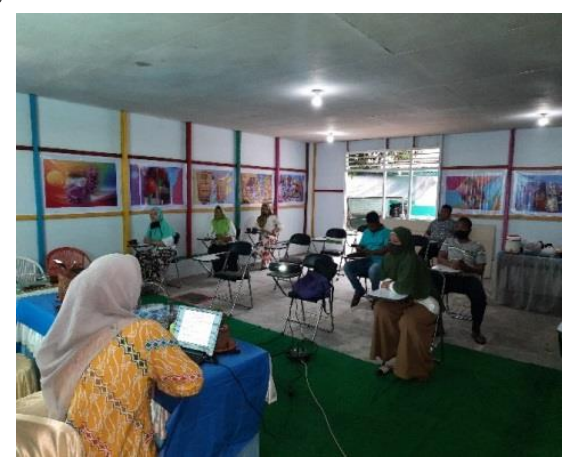

Gambar 5. Ceramah pengelolaan keuangan

\section{Demonstrasi tentang langkah-langkah} melakukan pengelolaan sampai transaksi penjualan produk

Pada tahap ini tim pengabdi melakukan demonstrasi pengelolaan produk / barang yang akan dijual pada website. Tim melakukan simulasi dengan menunjukkan kepada peserta cara melakukan penambahan produk, melakukan update, menghapus produk sampai mengelola stok produk. Selanjutnya melakukan simulasi pembelian produk, proses transfer dan proses pengiriman barang.

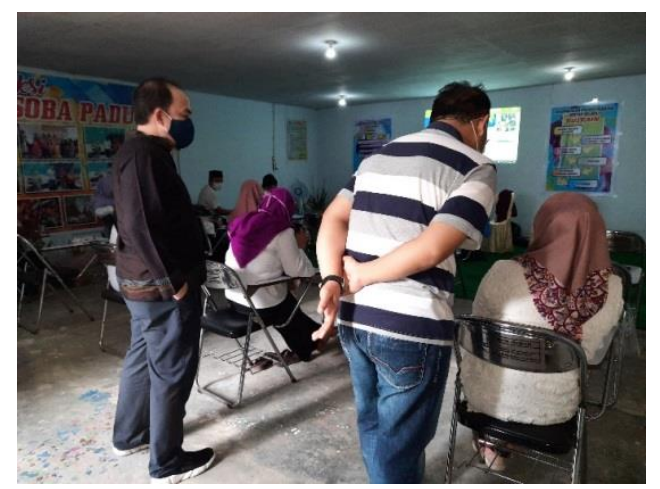

Gambar 6. Demonstrasi pengelolaan dan transaksi produk

4. Demonstrasi pembuatan laporan laba rugi, laporan neraca, penyusunan arus kas.

Pada tahap ini tim melakukan demonstrasi cara membuat laporan laba rugi, laporan neraca, 
penyusunan arus kas dengan melakukan pendampingan kepada peserta.

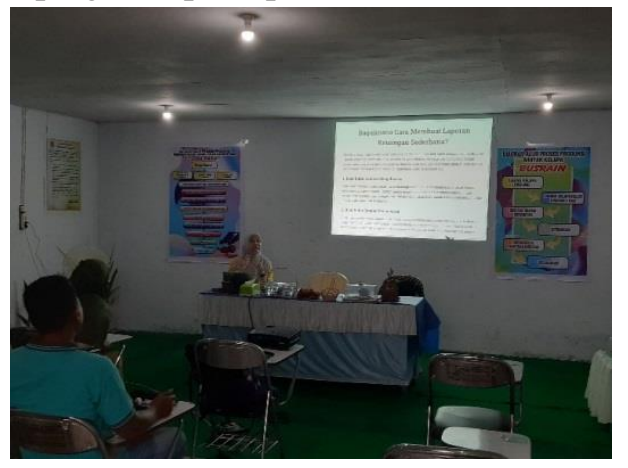

Gambar 7. Demonstrasi pembuatan laporan laba rugi, laporan neraca, penyusunan arus kas

\section{Latihan pengelolaan Akun Admin dan Akun Pelapak pada website.}

Pada tahap ini peserta diberikan sebuah latihan berupa simulasi pengelolaan akun Admin yang mengelola beberapa pelapak atau penjual. Untuk pengelolaan akun Admin terdapat beberapa penyampaian kepada peserta terutama pengelolaan status transfer,pengelolaan invoce pemesanan produk dll. Untuk akun Pelapak terdapat beberapa penekanan pada pelatihan website seperti cara mengupdate status transfer, info status barang, pengelolaan laporan dll.

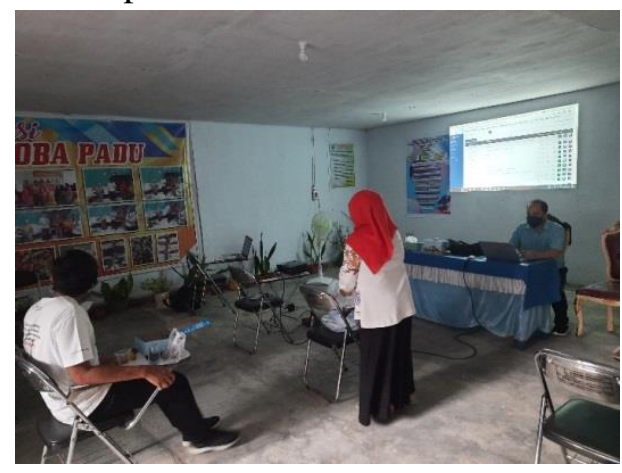

Gambar 8. Latihan pengelolaan Akun

\section{Evaluasi kegiatan}

Evaluasi kegiatan dilakukan untuk melihat apabila ada diantara peserta yang belum mengetahui secara detil penggunaan fasilitas atau fitur yang ada pada website misalnya bagaimana penanganan kesalahan pada saat mengupdate dan melakukan penghapusan produk. Disamping itu ada beberapa peserta yang belum memahami pengelolaan keuangan misalnya penbuatan laporan laba rugi, tim melakukan pendampingan kepada peserta tersebut.

Pada tahap ini juga dilakukan kustomisasi website yang disesuaikan dengan kondisi dan permintaan dari mitra. Untuk kustomisasi website, beberapa fitur yang ditambahakan seperti penambahan fitur chatting, penambahan akun penjual/pelapak, penambahan fitur rekening dan kategori produk serta pengelolaan transfer pada akun Admin, pembeli dan penjual.

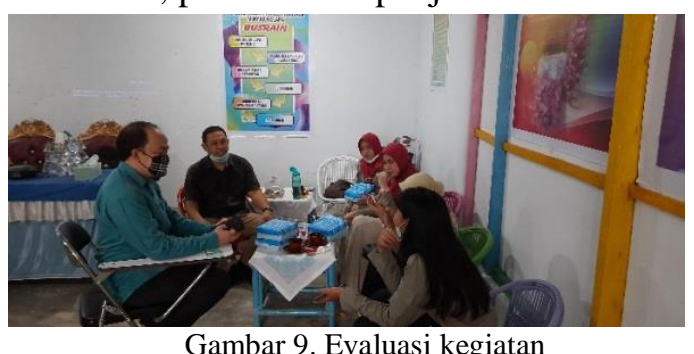

IV. KESIMPULAN

Kegiatan ini memberikan dampak positip bagi UKM "soba padu" yaitu website ini dapat dapat digunakan untuk media promosi dan melakukan transaksi penjualan secara online. Dari website yang ada sudah terdapat beberapa produk yang dipromosikan dan dijual pada website tersebut. Tercatat ada kurang lebih 34 produk yang ditawarkan pada website sobapadu.com.

Disamping itu juga peserta pelatihan telah mengetahui bagaimana melakukan pengelolaan dan pembuatan laporan keuangan secara sederhana dengan cara yang benar yang dapat dilihat dari tersusunnya laporan keuangan dari UKM ini.

\section{UCAPAN TERIMA KASIH}

Ucapan terima kasih disampaikan kepada Direktorat Jendral Pendidikan Tinggi yang telah memberikan hibah pengabdian. Ucapan yang sama juga disampaikan pula kepada Rektor Universitas Negeri Gorontalo atas arahan dan pembinaanya selama proses kegiatan Pengabdian Masyarakat berlangsung. Demikian pula ucapan terima kasih disampaikan kepada Ketua Lembaga Pengabdian Kepada Masyarakat dan Tim LPPM yang telah memberi fasilitas, melakukan monitoring, dan mengevaluasi kegiatan PKM hingga selesai. 


\section{DAFTAR PUSTAKA}

Bismala, lila. (2016). Model Manajemen Usaha Mikro Kecil dan Menengah (UMKM) untuk Meningkatkan Efektivitas Usaha Kecil Menengah. Jurnal Entrepreneur dan Entrepreneurship, 5(1).

Jonathan, William, Lestari, S. (2015). Sistem Informasi UKM berbasis website pada desa sumber jaya. Jurnal Pengabdian Pada Masyarakat. 1(1).

Muslich Mohammad. (2003). Manajemen Keuangan Modern. Jakarta: PT Bumi Aksara

Supeni, R.E. \& Sari, M.I. 2011. Upaya Pemberdayaan Ekonomi Perempuan Melalui Pengembangan Manajemen Usaha Kecil. Laporan Seminar Tidak Diterbitkan. Jember: Fakultas Ekonomi UNIMUS

Umami, nailariza. (2019). Peran Manajemen Keuangan Pada Usaha Mikro Kecil Dan Menengah (UMKM) Batik Dalam Memajukan Sektor Kewirausahaan, Jurnal pendidikan dan ekonomi, 3(1). 